\title{
The General Mechanisms of Attack of Nitrogen Nucleophiles on Carbonyl Compounds. Facts That Determine the Change of the Rate-pH Profiles
}

\author{
Inês Maria Costa Brighente ${ }^{a}$, and Rosendo Augusto Yunes ${ }^{a} *$ \\ ${ }^{a}$ Departamento de Química, Universidade Federal de Santa Catarina, \\ Campus Universitário, Trindade, 88040-900 Florianópolis - SC, Brazil
}

Received: December 21, 1996; July 15, 1997

Foi descrito um mecanismo geral para a etapa de ataque da reação de nucleófilos nitrogenados com compostos carbonílicos para formar intermediários de adição neutro. Este mecansimo geral está baseado na importância relativa do mecanismo "concertado" com respeito ao mecanismo "por etapas". O mecanismo "concertado" envolve o ataque da base nitrogenada ao composto carbonílico catalisado pelo íon hidrônio, enquanto que o mecanismo "por etapas" envolve a formação prévia de um intermediário tetraédrico zwiteriônico $\left(\mathrm{T}^{\ddagger}\right)$, com posterior transferência de próton a partir do íon hidrônio. A importância relativa destes dois passos origina três diferentes tipos de perfis de velocidade em funcão do $\mathrm{pH}$. A importância do mecanismo "por etapas" depende da estabilidade do intermediário $\mathrm{T}^{\ddagger}$, que por sua vez depende do pKa do nucleófilo nitrogenado e da constante de equilíbrio $\left(\mathrm{K}_{\mathrm{ad}}\right)$ para a formação do intermediário neutro $\left(\mathrm{T}^{0}\right)$. A comparação entre as reações de p-clorobenzaldeído e norcanfor com diferentes nucleófilos nitrogenados mostra que o mecanismo geral depende de cada tipo de composto carbonílico. Isto deve-se a dois fatos: A grande influência dos efeitos estéricos e eletrônicos na estrutura dos compostos carbonílicos, e o fato de que o valor do $\mathrm{pKa}$ do nucleófilo nitrogenado é o fator mais importante na predição dos perfis. O pKa do nucleófilo nitrogenado está mais relacionado com a estabilidade do intermediário $\mathrm{T}^{\ddagger}$ que de $\mathrm{T}^{0}$, enquanto que o valor de $\mathrm{K}_{\mathrm{ad}}$ está relacionado apenas com a estabilidade do intermediário $\mathrm{T}^{0}$.

It have been described a general mechanism for the attack step of the reactions between nitrogen nucleophiles and carbonyl compounds to form a neutral tetrahedral addition intermediate. This general mechanism is based on the relative importance of the "concerted" hydronium-ion catalyzed attack of the nitrogen base on the carbonyl compound with respect to the "step wise" mechanism that involves the previous formation of a zwitterionic tetrahedral intermediate $\left(\mathrm{T}^{ \pm}\right)$and the posterior proton transfer to it from the hydronium-ion. The relative importance of this pathway gives origin to three kinds of profile rates vs $\mathrm{pH}$ for these reactions. On the other hand, the importance of the "stepwise" mechanism was attributed to a dependence on the stability of the $\mathrm{T}^{ \pm}$intermediate that is related to the $\mathrm{pKa}$ of the nitrogen base and the $\mathrm{K}_{\mathrm{ad}}$ (the equilibrium constant for the formation of the neutral tetrahedral addition intermediate $\left(\mathrm{T}^{0}\right)$ ). The comparison of the reactions of p-chlorobenzaldehyde and norcamphor with different nitrogen nucleophiles led to the observation that the general mechanism depends on each type of carbonyl compound. This is due to the great influence of the steric and electronic effects of the compound's structure, and the fact that the pKa value of the nitrogen base, which is more related to the stability of the $\mathrm{T}^{ \pm}$than the $\mathrm{T}^{0}$ intermediate, is more important as a factor of prediction of the profiles than the value of $\mathrm{K}_{\mathrm{ad}}$, this value being more related to the stability of the $\mathrm{T}^{0}$ intermediate.

Keywords: carbonyl compounds, nitrogen nucleophiles, general mechanism of attack 


\section{Introduction}

Sayer et $a l .{ }^{1}$ have described a general mechanism for the reaction between nitrogen nucleophiles and carbonyl compounds in aqueous solution, based on Scheme 1. This generalization is based on the relative importance of the hydronium-ion catalyzed concerted attack of the nitrogen nucleophile on the carbonyl compound (pathway I - "concerted mechanism") with respect to a mechanism that involves the previous formation of a zwitterionic tetrahedral intermediate $\left(\mathrm{T}^{ \pm}\right)$and the posterior proton transfer to it from the hydronium-ion (pathway II - "step wise mechanism"). The importance of stepwise pathway II depends on the stability of the intermediate $\mathrm{T}^{ \pm}$which is related to the $\mathrm{pKa}$ of the nitrogen nucleophile and to the equilibrium constant value $\mathrm{K}_{\mathrm{ad}}$ for the formation of the neutral addition tetrahedral intermediate $\mathrm{T}^{0}$ from the reagents.

The relative importance of pathway I with respect to pathway II originates different kinds of shape of the profile of $\log \mathrm{k}_{2}\left(\mathrm{k}_{2}=\right.$ second-order rate constant $) v s$. $\mathrm{pH}$ for these reactions. Three profiles were indicated by Sayer ${ }^{1}$, called types A, B and C. These will be discussed later.

It should be noted that Sayer et al. ${ }^{1}$ based their studies only on the reactions between benzaldehyde and substituted benzaldehydes with amines of different basicity. Thus, an important question is whether the pKa of the amine and the equilibrium constant $\mathrm{K}_{\mathrm{ad}}$ are of sufficiently equal importance to enable prediction of the profile of reactions of non-aromatic carbonyl compounds with amines.

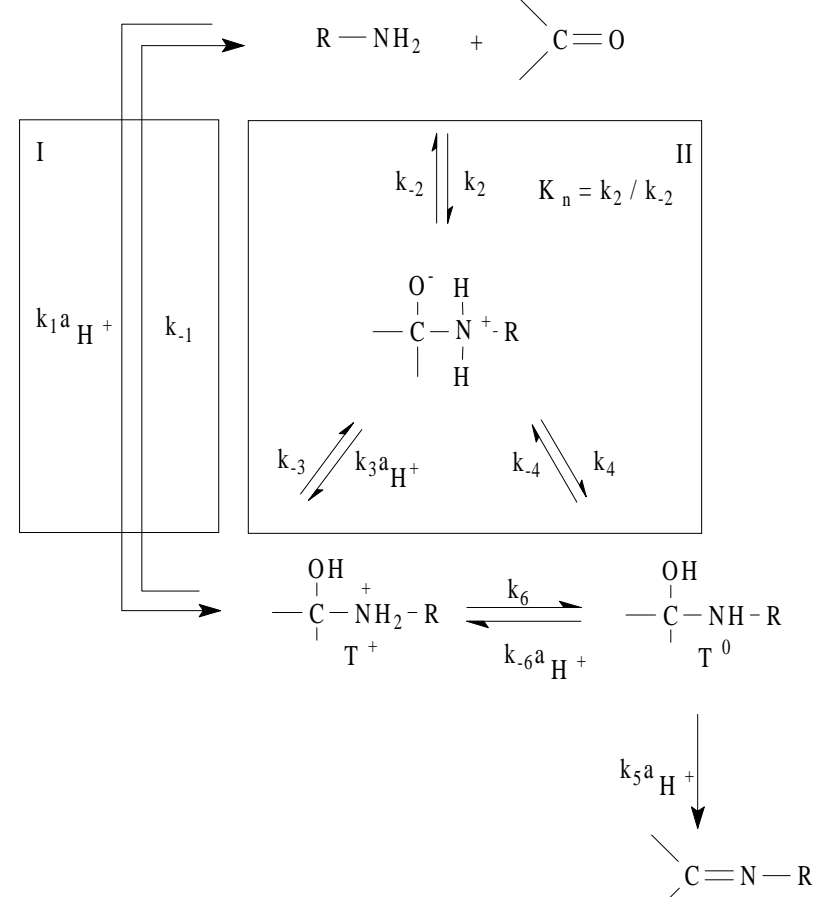

Scheme 1.
The reaction between norcamphor, a bicyclic ketone of fixed geometry ${ }^{2-4}$, with amines of different basicity, was studied in order to evaluate the above- mentioned question.

\section{Experimental}

\section{Materials}

Organic reagents employed were commercially available products and were either redistilled or recrystallyzed. Inorganic chemicals and carboxylic acids used in buffers were of reagent grade and were used without further purification.

\section{Kinetics}

Reaction of the carbonyl compounds with nitrogen nucleophiles in water at $25.0{ }^{\circ} \mathrm{C}$ and ionic strength $0.5 \mathrm{M}$ $(\mathrm{KCl})$ were followed on a Varian DMS 80 spectrophotometer, equipped with a thermostated cell holder, by monitoring the formation of the oxime at $240 \mathrm{~nm}$, the nitrone at 255 $\mathrm{nm}$, the semicarbazone at $255 \mathrm{~nm}$, and the phenylhydrazone at $320 \mathrm{~nm}$. The concentration of norcamphor and ciclopentanone did not exceed $3.3 \times 10^{-2} \mathrm{M}$. A sufficient excess of nitrogen nucleophile was employed to ensure pseudo first-order kinetic behaviour.

The determination of the rate constants was carried out using known procedures ${ }^{5}$. Reactions were followed for three half-lives $\left(\mathrm{t}_{1 / 2}\right)$ and first-order rate constants $\left(\mathrm{k}_{\mathrm{obs}}\right)$ were calculated by computer. Apparent second-order rate constants ( $\mathrm{k}_{2} \mathrm{ap}$ ) were calculated by dividing the first-order rate constants $\left(\mathrm{k}_{\mathrm{obs}}\right)$ by the concentration of the free nitrogen nucleophile, Eq. 1. The experimental error in the determination of the pseudo-first order constants $\left(\mathrm{k}_{\mathrm{obs}}\right)$ was $\pm 2 \%$.

$$
\mathrm{k}_{2} \text { ap }=\frac{\mathrm{k}_{\mathrm{obs}}}{[\mathrm{Nu}]_{1}} \mathrm{fc}
$$

where $\mathrm{fc}=1+\mathrm{K}_{\mathrm{ad}}[\mathrm{Nu}]_{1}$, and $[\mathrm{Nu}]_{1}$ is the concentration of free nitrogen nucleophile, calculated by the equation of Henderson-Hasselbalch.

Steady-state treatment of the mechanism in Scheme 1 yields Eqs. 2 and 3 for product formation in the regions of rate-determining neutral intermediate formation $\left(\mathrm{k}_{\mathrm{ad}}\right)$ and dehydration $\left(\mathrm{k}_{\mathrm{deh}}\right)$, respectively.

$$
\begin{aligned}
& \mathrm{k}_{\mathrm{ad}}=\frac{\mathrm{k}_{\mathrm{obs}}}{[\mathrm{Nu}]_{1}}=\mathrm{k}_{1} \mathrm{a}_{\mathrm{H}+}+\frac{\mathrm{k}_{2}\left(\mathrm{~K}_{\mathrm{n}} \mathrm{k}_{4}+\mathrm{K}_{\mathrm{n}} \mathrm{k}_{3} \mathrm{a}_{+}\right)}{\left(\mathrm{k}_{2}+\mathrm{K}_{\mathrm{n}} \mathrm{k}_{4}+\mathrm{K}_{\mathrm{n}} \mathrm{k}_{3} \mathrm{a}_{\mathrm{H}+}\right)} \\
& \mathrm{k}_{\mathrm{deh}}=\frac{\mathrm{k}_{\mathrm{obs}}}{[\mathrm{Nu}]_{1}} \mathrm{fc}=\frac{\mathrm{k}_{\mathrm{ad}} \mathrm{K}_{\mathrm{ad}} \mathrm{k}_{5} \mathrm{a}_{\mathrm{H}+}}{\left(\mathrm{k}_{\mathrm{ad}}+\mathrm{K}_{\mathrm{ad}} \mathrm{k}_{5} \mathrm{a}_{+}\right)}
\end{aligned}
$$

$\mathrm{k}_{2}$ ap was calculated employing Eq. 4, together with the rate constants in Table 2.

$$
\mathrm{k}_{2} \mathrm{ap}=\frac{\mathrm{k}_{\mathrm{ad}} \mathrm{k}_{\mathrm{deh}}}{\left(\mathrm{k}_{\mathrm{ad}}+\mathrm{k}_{\mathrm{deh}}\right)}
$$


Table 1. Type of Profile, pKa of the Amine and Equilibrium Constants $\left(\mathrm{K}_{\mathrm{ad}}\right)$ for Addition Intermediate Formation from Norcamphor and Different Amines at $25^{\circ} \mathrm{C}^{\mathrm{a}}$.

\begin{tabular}{lccc}
\hline Amine & pKa & $\begin{array}{c}\text { Type of } \\
\text { profile }\end{array}$ & $\mathrm{K}_{\mathrm{ad}}\left(\mathrm{M}^{-1}\right)$ \\
\hline Phenylhydroxylamine & $1.96^{\mathrm{c}}$ & $\mathrm{A}$ & \\
Semicarbazide & $3.65^{\mathrm{d}}$ & $\mathrm{A}$ & $0.064 \pm 0.006$ \\
Methoxyamine & $4.70^{\mathrm{e}}$ & $\mathrm{A}$ & $0.049 \pm 0.007$ \\
Phenylhydrazine & $5.25^{\mathrm{f}}$ & $\mathrm{A}$ & \\
N-Methylhydroxylamine & $5.97^{\mathrm{d}}$ & $\mathrm{B}$ & $0.068 \pm 0.007$ \\
Hidroxylamine $^{\mathrm{b}}$ & 5.96 & $\mathrm{~B}$ & $0.58 \pm 0.07$ \\
\hline
\end{tabular}

${ }^{\mathrm{a}}$ Ionic strength $0.5(\mathrm{KCl})$ and $20 \%$ ethanol v/v, $[\mathrm{C}=\mathrm{O}]=0.033 \mathrm{M}$. ${ }^{\mathrm{b}}$ Ref. 8. ${ }^{\mathrm{c}}$ Ref. 10. ${ }^{\mathrm{d}}$ Ref. 11. ${ }^{\mathrm{e}}$ Ref. 12. ${ }^{\mathrm{f}}$ Ref. 13.

Third-order rate constants $\left(\mathrm{k}_{1}, \mathrm{~K}_{\mathrm{n}} \mathrm{k}_{3}, \mathrm{~K}_{\mathrm{ad}} \mathrm{k}_{5}\right)$ were obtained from the slopes of plots of apparent second-order constants against the concentration of hydronium-ion. The $\mathrm{pH}$-independent rate constants $\left(\mathrm{k}_{2}, \mathrm{~K}_{\mathrm{n}} \mathrm{k}_{4}\right)$ were obtained directly from the plot of $\log \mathrm{k}_{2}$ ap $v s$. $\mathrm{pH}$.

\section{Equilibrium Constants}

The equilibrium constants - $\mathrm{K}_{\mathrm{ad}}$ - for the addition intermediate formation from several amines with norcamphor and hydroxylamine with ciclopentanone in aqueous solution and ionic strength $0.5 \mathrm{M}(\mathrm{KCl})$ were determined spectrophotometrically ${ }^{6}$, from the initial decrease in absorbance of the carbonyl group at $285 \mathrm{~nm}$ extrapolated to zero time, on mixing a solution of ketone with several concentrations of amines, at pH 8.5 (0.01 $\mathrm{M}$ borate buffer). At this $\mathrm{pH}$, dehydration of the addition intermediate is relatively slow, so that the observed absorbance could be extrapolated to zero time to determine the initial rapid decrease in ketone absorbance caused by addition intermediate formation. The calculated values of the fraction of ketone converted to addition intermediate $\left(\mathrm{T}^{0}\right)$ were based on an assumed absorbance of zero for the addition compound at $285 \mathrm{~nm}$. The measurements were made in triplicate for each concentra- tion of amine, using the equation $\mathrm{K}_{\mathrm{ad}}=[\mathrm{C}=\mathrm{O}]_{\mathrm{t}}-[\mathrm{C}=\mathrm{O}]_{1}$ / $\left\{[\mathrm{C}=\mathrm{O}]_{1} \times\right.$ [hydroxylamine $\left.]\right\}$, where $[\mathrm{C}=\mathrm{O}]_{\mathrm{t}}$ is the initial carbonyl concentration and $[\mathrm{C}=\mathrm{O}]_{1}$ is the free carbonyl concentration.

\section{Results and Discussion}

In order to discuss the results of this work, we should consider previously the three types of profiles (A, B, C) indicated by Sayer, ${ }^{1}$ and a fourth profile (D) indicated by ourselves $^{7,8}$.

Profile of type A: For very weakly basic amines and/or carbonyl compound for which the value of $\mathrm{K}_{\mathrm{ad}}$ is small, the tetrahedral zwitterionic intermediate should be unstable and consequently the pathway I is predominant. The profile exhibits a linear dependence of the rate as a function of the $\mathrm{pH}$ corresponding to hydronium-ion catalized attack $\left(\mathrm{k}_{1}\right)$ at low $\mathrm{pH}$. When the $\mathrm{pH}$ is increased, a break of the linearity with a $\mathrm{pH}$-independent region corresponding to the intramolecular proton transfer in the intermediate $\mathrm{T}^{ \pm}\left(\mathrm{K}_{\mathrm{n}} \mathrm{k}_{4}\right)$ appers. Finally, there emerges a new $\mathrm{pH}$-dependent region corresponding to the hydronium-ion catalized dehydration of the intermediate $\mathrm{T}^{0}\left(\mathrm{~K}_{\mathrm{ad}} \mathrm{k}_{5}\right)$. (Fig. 1, III).

Profile of type $\mathrm{B}$ : for moderate basic amine or moderate values of the $\mathrm{K}_{\mathrm{ad}}$, the contribution of the pathway (II) increases. The profile shows two breaks of linearity with five different kinetic regions: the hydronium-ion catalyzed attack at low $\mathrm{pH}$, the $\mathrm{pH}$-independent uncatalyzed attack $\left(\mathrm{k}_{2}\right)$, the hydronium-ion proton transfer to the $\mathrm{T}^{ \pm}$intermediate $\left(\mathrm{K}_{\mathrm{n}} \mathrm{k}_{3}\right)$, the $\mathrm{pH}$ independent intramolecular proton transfer in the $\mathrm{T}^{ \pm}$intermediate, and the hydronium-ion catalyzed dehydration of $\mathrm{T}^{0}$. (Fig. 1, II).

Profile of type C: For very strong basic amines or carbonyl compound with high values of $\mathrm{K}_{\mathrm{ad}}$, the stability of the $\mathrm{T}^{ \pm}$intermediate is increased still further, so that the rate pathway II is greater than the hydronium-ion catalyzed dehydration of $\mathrm{T}^{0}$, giving a profile where the only change in rate-determining step is the transition at low $\mathrm{pH}$ from uncatalyzed attack to hydronium ion-catalyzed dehydration of $\mathrm{T}^{0}$ (Fig. 1, I).

Table 2. Kinetic Constants for Product Formation from Different Reactions ${ }^{\mathrm{a}}$.

\begin{tabular}{|c|c|c|c|}
\hline Reaction & $\begin{array}{c}\text { Norcamphor } \\
\text { x } \\
\text { Methoxyamine } \\
\end{array}$ & $\begin{array}{c}\text { Norcamphor } \\
x \\
\text { N-methylhydroxylamine }\end{array}$ & $\begin{array}{l}\text { Ciclopentanone } \\
\text { x } \\
\text { Hydroxylamine } \\
\end{array}$ \\
\hline $\mathrm{k}_{1}\left(\mathrm{M}^{-2} \sec ^{-1}\right)$ & $1.00 \times 10^{2}$ & $5.62 \times 10^{2}$ & 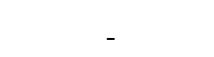 \\
\hline $\mathrm{k}_{2}\left(\mathrm{M}^{-1} \sec ^{-1}\right)$ & - & $5.62 \times 10^{2}$ & $7.10 \times 10^{2}$ \\
\hline $\mathrm{K}_{\mathrm{n}} \mathrm{k}_{3}\left(\mathrm{M}^{-2} \sec ^{-1}\right)$ & - & $3.16 \times 10^{3}$ & - \\
\hline $\mathrm{K}_{\mathrm{n}} \mathrm{k}_{4}\left(\mathrm{M}^{-1} \mathrm{sec}^{-1}\right)$ & $2.04 \times 10^{-1}$ & $2.51 \times 10^{1}$ & - \\
\hline $\mathrm{K}_{\mathrm{ad}} \mathrm{k}_{\mathrm{H}}+\left(\mathrm{M}^{-2} \sec ^{-1}\right)$ & $1.00 \times 10^{5}$ & $1.26 \times 10^{5}$ & $9.47 \times 10^{5}$ \\
\hline
\end{tabular}

\footnotetext{
${ }^{\mathrm{a}}$ Ionic strength $0.5(\mathrm{KCl})$ and $20 \%$ ethanol v/v, $[\mathrm{C}=\mathrm{O}]=0.033 \mathrm{M}$.
} 


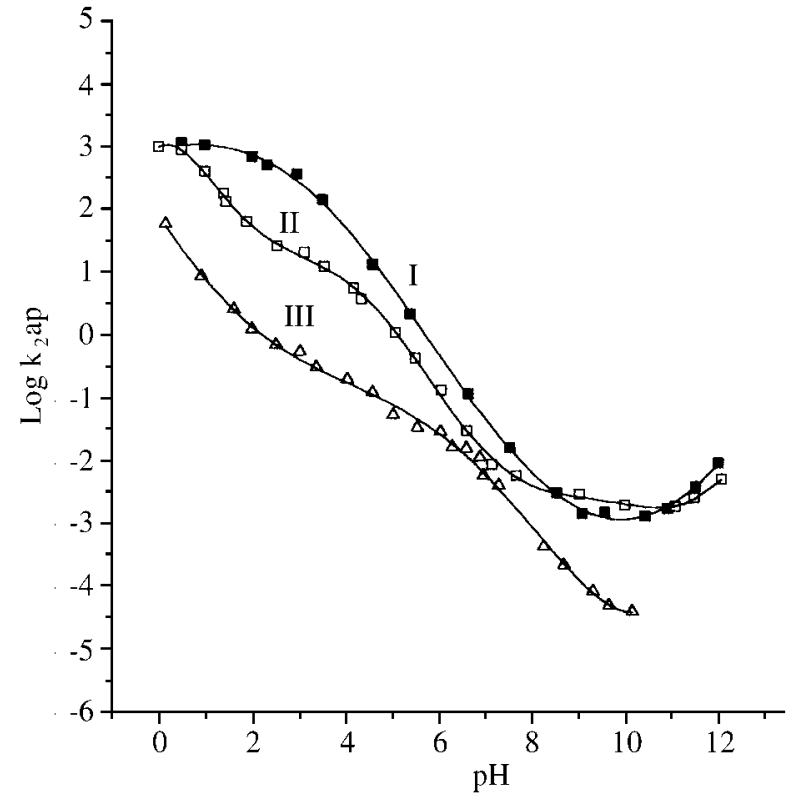

Figure 1. $\mathrm{pH}$ dependence of the logarithms of apparent second-order rate constants for product formation from hydroxylamine and cyclopentanone (I), N-methylhydroxylamine and norcamphor (II) and methoxyamine and norcamphor (III) in ethanol $20 \%$ at $25{ }^{\circ} \mathrm{C}$, ionic strength $0.5 \mathrm{M}$.

Profile of type D: Corresponds to the case in which dehydration of the neutral addition intermediate is the rate-determining step over the whole $\mathrm{pH}$ range $\mathrm{e}^{7,8}$.

The basicity of the amines studied in this work, the values of $K_{a d}$ and the type of profile determined, are indicated in Table 1.

Figure 1 shows the plot of $\log \mathrm{k}_{2} \mathrm{ap}\left(\mathrm{k}_{2} \mathrm{ap}=\right.$ apparent second-order rate constant) as a function of $\mathrm{pH}$ for the reactions of hydroxylamine with cyclopentanone (profile C), methoxyamine and $\mathrm{N}$-methylhydroxylamine with norcamphor (profiles A and B respectively).

It may be observed that from phenylhydroxylamine with $\mathrm{pKa}=1.96$ until phenylhydrazine $\mathrm{pKa}=5.25$, and with the $\mathrm{K}_{\mathrm{ad}}$ values determined only for semicarbazide $\mathrm{K}_{\mathrm{ad}}=$ $0.064 \mathrm{M}^{-1}$ and methoxyamine $\mathrm{K}_{\mathrm{ad}}=0.049 \mathrm{M}^{-1}$, a profile of type A is obtained. With the moderately strong basic Nmethylhydroxylamine $\mathrm{pKa}=5.97$, the profile changes to type B. However, its $K_{a d}$ value $\left(K_{a d}=0.068 \mathrm{M}^{-1}\right)$ is similar to that of semicarbazide and methoxyamine, and cannot be considered to indicate or permit the prediction of change of profile. The important difference of behaviour of semicarbazide and methoxyamine, in their reactions with norcamphor compared to their reactions with p-chlorobenzaldehyde $^{1}$, should be observed. In the latter case, methoxyamine exhibits a $\mathrm{K}_{\mathrm{ad}}=13.4 \mathrm{M}^{-1}$, which is approximately 4 times greater than that of semicarbazide where $\mathrm{K}_{\mathrm{ad}}=3.1 \mathrm{M}^{-1}$, giving a profile of type $\mathrm{B}$, while semicarbazide gives a profile of type A. Evidently, effects of the structure of norcamphor change the stability of the intermediates $\mathrm{T}^{0}$ and $\mathrm{T}^{ \pm}$and of the transition state of the "con- certed" acid catalyzed attack mechanism in its reaction with semicarbazide and methoxyamine. It should also be noted that phenylhydrazine-p-sulfonate, with a $\mathrm{pKa}=4.90$ that is greater than that of semicarbazide, but with a $\mathrm{K}_{\mathrm{ad}}=1.8 \mathrm{M}^{-1}$ (equilibrium constant with p-chlorobenzaldehyde) that is smaller, exhibits a profile of type $B^{1}$. In this case, it should be observed that the pKa of the amine is also more consistent with the predicted profile.

In the case of the reaction of norcamphor with hydroxylamine, a nitrogen nucleophile of similar basicity to $\mathrm{N}$ methylhydroxylamine, considering the value of $\mathrm{K}_{\mathrm{ad}}=0.58 \mathrm{M}^{-1}$ which is approximately 10 times greater than that of semicarbazide, the change of profile from A to $\mathrm{B}$ could be predicted. However, the reaction of cyclopentanone with hydroxylamine exhibits a similar $\mathrm{K}_{\mathrm{ad}}=0.53 \mathrm{M}^{-1}$ but a profile of type $\mathrm{C}^{9}$.

The small value $\mathrm{K}_{\mathrm{ad}}$ of $\mathrm{N}$-methylhydroxylamine $\left(\mathrm{K}_{\mathrm{ad}}=0.068 \mathrm{M}^{-1}\right)$ compared with that of hydroxylamine $\left(\mathrm{K}_{\mathrm{ad}}=0.58 \mathrm{M}^{-1}\right)$ must be caused by the steric effects of the methyl group bonded to the nitrogen atom, and this fact affects the value of $\mathrm{K}_{\mathrm{ad}}$ as a parameter of prediction of the predominance of the "concerted" or the "stepwise" mechanism.

It has been suggested ${ }^{10}$ that in the reaction between hydroxylamine and norcamphor, the conformacional and electronic effects, and especially the hydrogen bond between the hydroxyl group of hydroxylamine and the negatively-charged carbonyl oxygen, stabilize the zwitterionic tetrahedral intermediate $\left(\mathrm{T}^{ \pm}\right)$, increasing the importance of pathway II and leading to the change of profile from A to B. The same stabilization must occur in the case of the $\mathrm{T}^{ \pm}$ intermediate of the reaction of $\mathrm{N}$-methylhydroxylamine and norcamphor.

On the other hand, in the case of the reaction of phenylhydroxylamine with furfural ${ }^{7}$ and benzaldehyde ${ }^{8}$, it has been demonstrated that the profile that should be of type A according to its pKa was in fact of type $\mathrm{D}$, where the dehydration of the $\mathrm{T}^{0}$ intermediate is the only rate-determining step over the entire range of the $\mathrm{pH}$-rate profile. In this case, it has been suggested ${ }^{8}$ that there should exist a mechanism of pre-association for the attack step which is different to that of pathways I or II.

These results indicate that the general mechanism should be considered for each type of carbonyl compound, due to the great influence of the steric and electronic effects of their structure. They also indicate that the $\mathrm{pKa}$ value of the amine, which is more related to the stability of the $\mathrm{T}^{ \pm}$ than the $\mathrm{T}^{0}$ intermediate, is more important as a factor of prediction than the value of $\mathrm{K}_{\mathrm{ad}}$ which is more related to the stability of the $\mathrm{T}^{0}$ intermediate.

The correlation of structure and reactivity with respect to the nucleophile considered in Scheme 1 leads to the prediction that a plot of $\log \mathrm{k}_{\mathrm{H}+}\left(\mathrm{k}_{1}\right.$ and $\mathrm{K}_{\mathrm{n}} \mathrm{k}_{3}$, corresponding to the rate constant for "concerted" and "stepwise" attack 
mechanism respectively) for hydronium-ion catalyzed neutral intermediate formation against $\log \mathrm{K}_{\mathrm{n}}$ (the equilibrium constant for formation of $\mathrm{T}^{ \pm}$intermediate from starting materials) should be non-linear, and for this reason, indicates that a change in the mechanism from "concerted" to "stepwise" occurs as the stability of $\mathrm{T}^{ \pm}$is increased.

Considering that:

$$
\mathrm{K}_{\mathrm{n}}=\mathrm{K}_{\mathrm{ad}} \mathrm{K}_{\mathrm{z}}
$$

where $\mathrm{K}_{\mathrm{z}}$ corresponds to isomerization of $\mathrm{T}^{0}$ to $\mathrm{T}^{ \pm}$, and $\Delta \log$ $\mathrm{K}_{\mathrm{z}}$ is equal to $0.8 \Delta \mathrm{pK}_{\text {nuc }}{ }^{1}$, it is possible to derive Eq. 5:

$$
\Delta \log \mathrm{K}_{\mathrm{n}}=\Delta \log \mathrm{K}_{\mathrm{ad}}+0.8 \Delta \mathrm{pK}_{\mathrm{nuc}}
$$

The slope of the plot of $\log \mathrm{k}_{\mathrm{H}}{ }^{+}$vs. $\left(\log \mathrm{K}_{\mathrm{ad}}+0.8 \mathrm{pK}_{\text {nuc }}\right)$ should measure the degree of resemblance of the transition state, of the "concerted" mechanism, with the $\mathrm{T}^{ \pm}$intermediate. For the diffusion-controlled protonation of $\mathrm{T}^{ \pm}$, this slope should be 1.0.

Figure 2 shows a plot of $\log \mathrm{k}_{\mathrm{H}}^{+} v s . \log \mathrm{K}_{\mathrm{ad}}+0.8 \mathrm{pKa}_{\text {nuc }}$ for semicarbazide $\left(\mathrm{k}_{1}=56 \mathrm{M}^{-2} \mathrm{~s}^{-1}\right)$, methoxyamine $\left(\mathrm{k}_{1}=\right.$ $\left.100 \mathrm{M}^{-2} \mathrm{~s}^{-1}\right)$, hydroxylamine $\left(\mathrm{k}_{1}=667 \mathrm{M}^{-2} \mathrm{~s}^{-1}\right.$ and $\mathrm{K}_{\mathrm{n}_{3}}=$ $\left.11200 \mathrm{M}^{-2} \mathrm{~s}^{-1}\right)^{8}$ and $\mathrm{N}$-methylhydroxylamine $\left(\mathrm{k}_{1}=562 \mathrm{M}^{-2}\right.$ $\mathrm{s}^{-1}$ and $\mathrm{K}_{\mathrm{n}} \mathrm{k}_{3}=3160 \mathrm{M}^{-2} \mathrm{~s}^{-1}$ ).

As has been established in previous works, ${ }^{10}$ the value of $\mathrm{k}_{3}$ for the reaction of hydroxylamine with norcamphor is not diffusion-controlled, and logically the same behaviour is expected for the reaction of $\mathrm{N}$-methylhydroxylamine and norcamphor. As the value $\mathrm{k}_{3}$ could be different for both amines, we take into consideration the line that passes through the two points giving a slope of 0.60 , and this slope

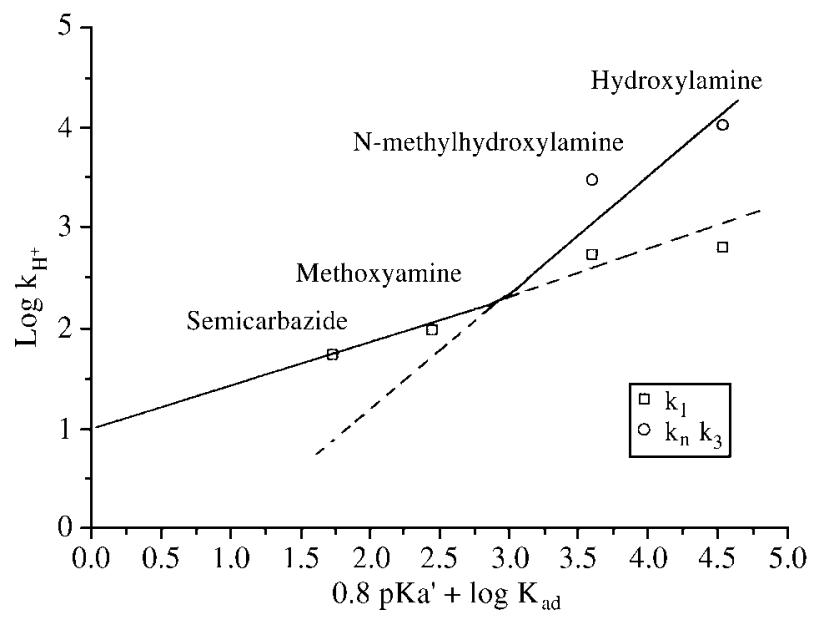

Figure 2. Dependence of the logarithms of the rate contants for hydronium-ion catalyzed addition intermediate formation from norcamphor and different nitrogen nucleophiles on $\mathrm{pKa}$ and $\log \mathrm{K}_{\mathrm{ad}}$ for the nucleophiles. The symbols (o) represents the stepwise $\left(K_{n} k_{3}\right)$ pathway, and the symbols $(\square)$ indicates the concerted (k1) pathway. The solid line represents the sum of the two pathways. is greater than the slope of least-squares line for the bases that exhibit the "concerted" mechanism $\left(\mathrm{k}_{1}\right)$ of value 0.42 $(r=0.96)$. In the case of $p$-chlorobenzaldehyde with different amines, the slope for the "stepwise" mechanism is 1.0 and the corresponding value for the "concerted" mechanism 0.33. This fact suggests that for norcamphor the transition state for the "concerted" mechanism is more similar to the $\mathrm{T}^{ \pm}$intermediate than in the case of p-chlorobenzaldehyde.

\section{Conclusions}

From the analysis of the reaction of different nitrogen nucleophiles with norcamphor, it is suggested that in the general mechanism for the attack step of the reactions of nitrogen nucleophiles and carbonyl compounds, forming a neutral tetrahedral intermediate, the $\mathrm{pKa}$ value of the nitrogen nucleophile is a more important parameter of prediction of the different $\log \mathrm{k}_{2} v s$. $\mathrm{pH}$ profiles than the value of $\mathrm{K}_{\mathrm{ad}}$ (equilibrium constant of the neutral addition intermediate formation).

\section{Acknowledments}

We are grateful to CNPq, FINEP and CAPES for financial support.

\section{References}

1.Sayer, J.M.; Pinsky, B.; Schonbrunn, A.; Washtien, W. J. Am. Chem. Soc. 1974, 96, 7998.

2. Chiang, J.F.; Wilcox, Jr, C.F.; Bauer, J.H. J. Am. Chem. Soc. 1968, 90, 3149.

3. Altona, A.; Sundaralingam, M. J. Am. Chem. Soc. 1970, 92, 1995.

4. Yokozeki, A.; Kuchitzu, K. Bull. Chem. Soc. jpn. 1970, 43, 2017.

5.Rosemberg, S.; Silver, S.M.; Sayer, J.M.; Jencks, W.P. J. Am. Chem. Soc. 1974, 96, 7986.

6. Jencks, W.P. J. Am. Chem. Soc. 1959, 81, 475.

7. Fett, R.; Simionatto, E.L.; Yunes, R.A. J. Phys. Org. Chem. 1990, 3, 620.

8. Brighente, I.M.C.; Budal, R.M.; Yunes, R.A. J. Chem. Soc. Perkin Trans. 1991, 861.

9. In preparation.

10. Brighente, I.M.C.; Vottero, L.R.; Terezani, A.J.; Yunes, R.A. J. Phys. Org. Chem. 1991, 4, 107.

11. Smith, R.M.; Martell, A.E.; Motekaitis, R.J. In Critical Stability Constants of Metal Complexes, Gaithersburg, USA, 1994.

12. Lamaty, G.; Roque, J.P.; Natat, A.; Silou, T. Tetrahedron 1986, 42, 2667.

13. Do Amaral, L.; Sandstron, W.A.; Cordes, E.H.. J. Am. Chem. Soc. 1966, 88, 2225. 